\title{
Did the introduction of maize into Europe provide enemy-free space to Ostrinia nubilalis? Parasitism differences between two sibling species of the genus Ostrinia
}

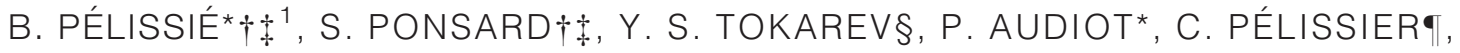 \\ R. SABATIER*, S. MEUSNIER* , J. CHAUFAUX**, M. DELOS††, E. CAMPAN \\ J. M. MALYSHAt, A. N. FROLOV†t \& D. BOURGUET* \\ *Centre de Biologie et de Gestion des Populations (CBGP) UMR INRA-IRD-CIRAD-Montpellier SupAgro, Campus International de Baillarguet, \\ Montferrier-sur-Lez Cedex, France \\ †Université de Toulouse, UPS, EDB (Laboratoire Evolution et Diversité Biologique), Toulouse, France \\ $\$ C N R S$; EDB (Laboratoire Evolution et Diversité Biologique); Toulouse, France \\ $\S$ Laboratory for Microbiological Control, All-Russian Institute for Plant Protection, St. Petersburg-Pushkin, Russia \\ - Laboratoire d'Ecologie Fonctionnelle, UMR 5245 (CNRS-UPS-INPT), Université P. Sabatier Toulouse III, Toulouse Cedex, France \\ **Unité Génétique Microbienne et Environnement, INRA La Minière, Guyancourt Cedex, France \\ $\dagger$ DRAF-SRPV, Cité Administrative Bât. E, Toulouse Cedex, France \\ †LLaboratory for Phytosanitary Diagnostics and Forecasts, All-Russian Institute for Plant Protection, St. Petersburg-Pushkin, Russia
}

Keywords:

agricultural pest;

ecological speciation;

enemy-free space;

Lydella thompsoni;

Macrocentrus cingulum;

microsporidia;

molecular detection;

Ostrinia nubilalis;

Ostrinia scapulalis;

Pseudoperichaeta nigrolineata.

\begin{abstract}
We examined whether maize offers enemy-free space (EFS) to its pest Ostrinia nubilalis, and may thereby have contributed to its divergence from the sibling species, Ostrinia scapulalis, feeding mainly on mugwort, when introduced into Europe five centuries ago. We collected Ostrinia larvae on maize (70 populations, 8425 individuals) and mugwort (10 populations, 1184 individuals) and recorded parasitism using both traditional (counting emerging parasitoids) and molecular methods (detection by specific polymerase chain reaction). The main parasitoid was Macrocentrus cingulum (Braconidae). On mugwort, parasitism was twice that on maize, and parasitoid-related mortality was 8 times higher. This suggests that maize affords substantial EFS to Ostrinia feeding on it. The lower Mortality:Infestation ratio in maize suggests that O. nubilalis' immune response might be stronger than that of $O$. scapulalis. If so, adapting to maize and diverging from $O$. scapulalis would decrease the impact of parasitism on $O$. nubilalis at both ecological and evolutionary levels.
\end{abstract}

\section{Introduction}

Acquiring the ability to feed on a new host may be a first step towards ecological speciation (Schluter, 2001; Rundle $\&$ Nosil, 2005) in phytophagous insects (Howard \& Berlocher, 1998; Drès \& Mallet, 2002). Evolving such ability can be facilitated if the new host offers enemy-free space (EFS; Jeffries \& Lawton, 1984; Ode, 2006), i.e. if a

Correspondence: Benjamin Pélissié, CEFE-CNRS, 1919 route de Mende, 34293 Montpellier Cedex 5, France. Tel.: +33 467613 259; fax: +33467412 138; e-mail: benjamin.pelissie@cefe.cnrs.fr

${ }^{1}$ Present address: CEFE-CNRS, 1919 Route de Mende, 34293 Montpellier Cedex 5, France. fitness loss experienced by the insect when feeding on the new host is offset by a fitness gain because of a lower level of parasitism and/or predation by natural enemies. Such situation may for instance arise when the new host is a recently introduced plant species that is little protected from phytophagous insects by co-adapted natural enemies (review in Price et al., 1980; Gratton $\delta$ Welter, 1999; Chen \& Welter, 2007).

Examples where EFS may have not only facilitated the colonization of a new host but also promoted host-associated differentiation between closely related taxa are scarce. They include the fruit fly Rhagoletis pomonella Walsh (Feder, 1995), several sister-taxa of the 
goldenrod-associated insect community (Stireman et al., 2005), and species of the lepidopteran genera Pieris (Ohsaki \& Sato, 1990, 1994) and Heliothis (Sisterson \& Gould, 1999; Oppenheim \& Gould, 2002).

The present work looks for evidence that maize (Zea mays L.), which was introduced into Europe ca. 500 years ago (Gay, 1999), offers EFS to the maize pest Ostrinia nubilalis Hübner (Lepidoptera: Crambidae) sensu Frolov et al. (2007), and may thereby contribute to its divergence from the sibling species Ostrinia scapulalis sensu Frolov et al. (2007). Both species are believed to be of Eurasian origin and currently occur in sympatry over a large part of their respective ranges in Europe. They form genetically (Bourguet et al., 2000; Martel et al., 2003; Leniaud et al., 2006; Malausa et al., 2007a,b) and ecologically (Thomas et al., 2003; Bethenod et al., 2005; Calcagno et al., 2007; Malausa et al., 2008) differentiated, but weakly interfertile (Malausa et al., 2005) taxa that feed on different host plants: $O$. nubilalis feeds mainly on maize, whereas $O$. scapulalis is thought to feed mainly on mugwort (Artemisia vulgaris L.) and hop (Humulus lupulus L.), both native to Eurasia. One scenario that might explain the co-existence of these two differentiated taxa (but see Malausa et al., 2007a) is that the introduction of maize into Europe triggered ecological speciation within an ancestral species close to the current $O$. scapulalis. As for most candidate cases of ecological speciation [e.g. Rhagoletis pomonella (Feder et al., 2003)], it is difficult if not impossible to ensure that the impact of geographic isolation on genetic divergence was minor. Nevertheless, such candidate cases provide insight into the mechanism(s) that may have contributed or still contribute to genetic isolation driven by divergent adaptation, i.e. to the kind of process that must be hypothesized to account for ecological speciation.

Berdegue et al. (1996) clarified that EFS can facilitate a shift from an original to an alternative host plant in a phytophagous taxon if two conditions are met: (1) on the original host plant, the fitness must be higher in the absence than in the presence of natural enemies and (2) in the presence of natural enemies the fitness must be higher on the alternative than on the original host plant.

Several natural enemies have been reported to cause substantial mortality to natural Ostrinia sp. populations across Europe, so that Berdegue et al.'s (1996) condition (1) is likely to be met. They include three main species of larval parasitoids (Thompson \& Parker, 1928; Baker et al., 1949; Grenier et al., 1990; Monetti et al., 2003; Thomas et al., 2003; Agustì et al., 2005): Lydella thompsoni Herting, Pseudoperichaeta nigrolineata Walker (both Diptera: Tachinidae) and Macrocentrus cingulum Reinhard [Hymenoptera: Braconidae, also referred to as M. abdominalis Fab., M. grandii Goidanich or M. gifuensis Ashmead (Thompson \& Parker, 1928; Parker, 1931; van Achterberg \& Haeselbarth, 1983)]. They also include Trichogramma brassicae, an egg parasitoid used for biological control (Smith, 1996). Lydella thompsoni (Hsiao et al., 1966 and included references, Galichet et al., 1985; Cagáň et al., 1999), P. nigrolineata (Martinez \& Reymonet, 1991) and Trichogramma sp. (Smith, 1996; Kuske et al., 2004) also parasitize other hosts, whereas reports of $M$. cingulum on hosts outside the genus Ostrinia are anecdotal (van Achterberg, 1993; De Nardo \& Hopper, 2004). Finally, Ostrinia sp. can be infected by intracellular parasites known as microsporidia (the main species infesting Ostrinia nubilalis being Nosema pyrausta sometimes referred to as Perezia pyraustae Paillot, Microsporida: Nosematidae; Kramer, 1959; Lewis et al., 2006).

Thomas et al. (2003) found that Ostrinia larvae collected on mugwort showed a higher mortality because of larval insect parasitoids than sympatric larvae collected from maize in the vicinity of Paris, France. This suggests that Berdegue et al.'s (1996) condition (2) could be fulfilled as well, although no general conclusion can be reached from this study alone, as it was performed at a single site and during a single year (Heard et al., 2006).

The present study extends Thomas et al.'s (2003) study to Ostrinia populations collected across France on mugwort and hop (O. scapulalis sensu Frolov et al., 2007), and maize (O. nubilalis sensu Frolov et al., 2007), and uses methods providing complementary information. We assessed the levels of parasitism with the traditional method of rearing larvae after they have completed their diapause, counting those yielding parasitoid pupae and identifying emerging parasitoids. In addition, we used molecular methods (Tilmon et al., 2000; Agustì et al., 2005) to specifically test for the presence of DNA of a particular parasite (M. cingulum, L. thompsoni, P. nigrolineata, microsporidia) in bulk DNA extracted from diapausing larvae, and thus detect the presence of parasites before diapause, independently of the mortality they might cause (Day, 1994).

\section{Materials and methods}

\section{Insect samples}

Sample A - Early in the winters 2002-2003, 2003-2004 and 2004-2005, we received samples of 64 populations of diapausing Ostrinia larvae collected in maize (Zea mays) fields across France by extension services of the French Ministry of Agriculture (Services Régionaux de Protection des Végétaux; Fig. 1, Table 1). Samples were preferentially taken from maize fields free of any insecticide treatments. At the beginning of the winter 2002-2003, we also collected samples of seven populations of diapausing larvae in mugwort stands (Artemisia vulgaris) located in central and northern France (Fig. 1, Table 1).

Sample $B$ - We also used a sample set collected by Malausa et al. (2007b) in the winters 2004-2005 and 2005-2006 (Table 2). In addition to maize and mugwort, these samples include populations from a third host plant: hop (Humulus lupulus). They came from six sites 


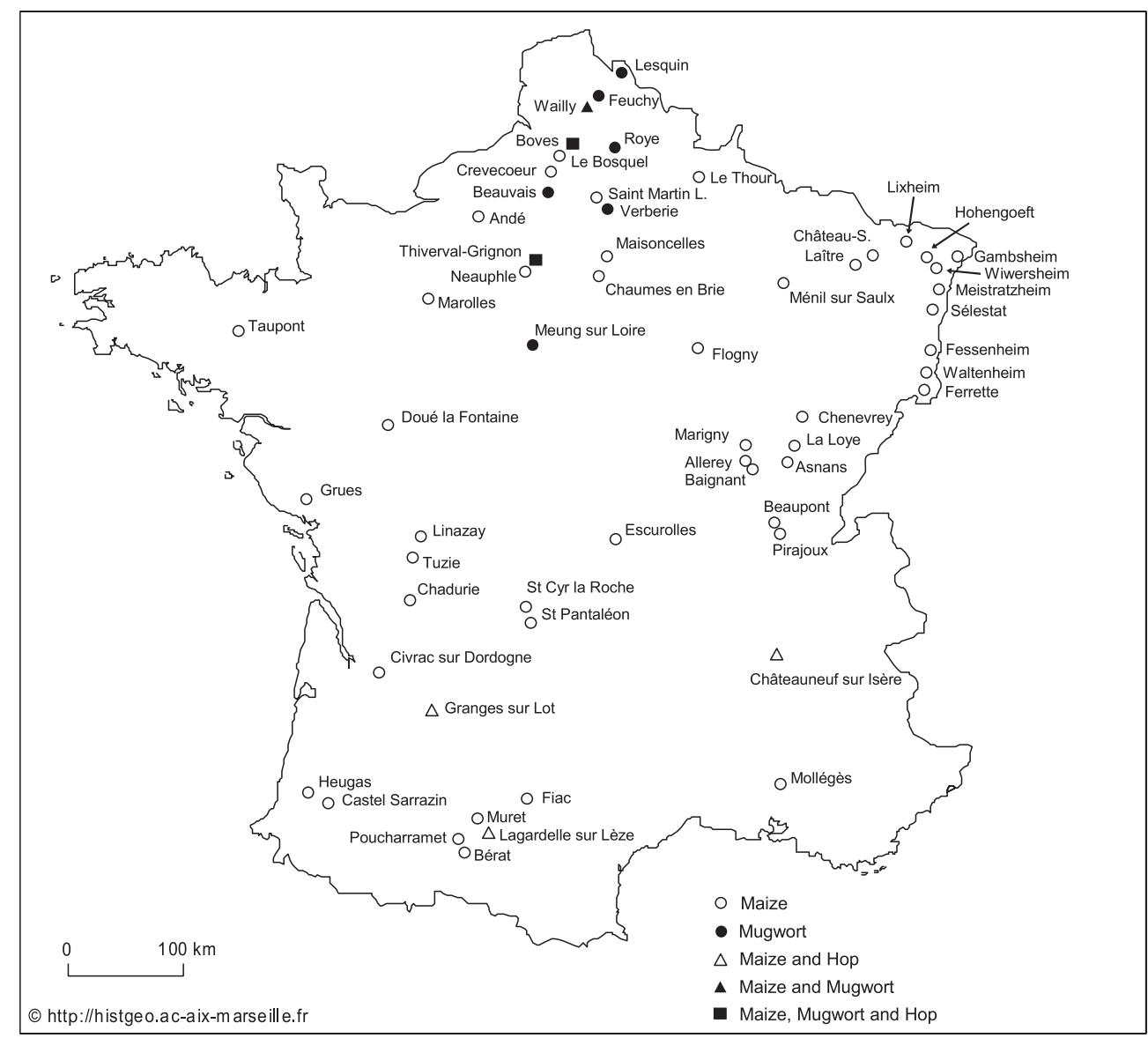

Fig. 1 Map of the sampling sites.

(Fig. 1) where maize and at least one of the two other plant species - mugwort or hop - could be found in close sympatry, i.e. at a distance $<2 \mathrm{~km}$. Within any given site (except Ile de France), samples from the two or three host species were collected within the same week. In all cases, they were frozen immediately upon returning to the laboratory.

We used specimens of the parasitoids M. cingulum, $P$. nigrolineata and $L$. thompsoni from various origins (Table 3) to design specific primers and to assess polymerase chain reaction (PCR) quality (positive controls).

\section{DNA extractions}

We extracted total genomic DNA from parasites and Ostrinia larvae from the whole body, except for the head of certain Ostrinia larvae, by using either the DNeasy Blood \& Tissue (Qiagen, Venlo, the Netherlands) or the PureGene Extraction kit (Gentra Systems, Minneapolis, MN, USA). We resuspended all pellets in $100 \mu \mathrm{L}$ of TE (10 mm Tris-HCl pH 8.0, 1 mm ethylenediaminetetraacetic acid) and stored extracts at $-20{ }^{\circ} \mathrm{C}$ until PCR amplification.

\section{Molecular detection of Lydella thompsoni and Pseudoperichaeta nigrolineata}

To detect parasitism by one of the two tachinid species, we used the two pairs of specific primers designed in the Cytochrome oxydase I (COI) gene by Agustì et al. (2005): FL3/RL8 for L. thompsoni and FP3/RP6 for P. nigrolineata. For all samples listed in Tables 2 and 4 (see below), we conducted PCR amplifications in $25 \mu \mathrm{L}$ containing $2 \mu \mathrm{L}$

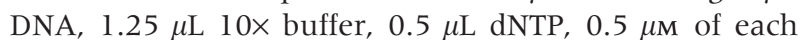
primer, $1 \mathrm{U}$ Taq polymerase (Qiagen) and $6.15 \mu \mathrm{L}$ of $\mathrm{H}_{2} \mathrm{O}$. PCR comprised an initial denaturation at $95{ }^{\circ} \mathrm{C}$ for 2 min, followed by 35 cycles of: $95{ }^{\circ} \mathrm{C}, 30 \mathrm{~s} ; 58{ }^{\circ} \mathrm{C}$ (for L. thompsoni) or $62{ }^{\circ} \mathrm{C}$ (for P. nigrolineata), $30 \mathrm{~s} ; 72{ }^{\circ} \mathrm{C}$, $40 \mathrm{~s}$, with a final elongation step at $72{ }^{\circ} \mathrm{C}$ for $5 \mathrm{~min}$. We separated PCR products by electrophoresis in 3\% agarose gels stained with ethidium bromide. All PCR amplifications included a negative and a positive control.

\section{Molecular detection of Macrocentrus cingulum}

To design specific primers to detect $M$. cingulum, we amplified a fragment of the COI gene in DNA extracts of 
Table 1 'Traditional' parasitism rates (\%) in samples of Ostrinia sp. populations collected on maize (Zea mays) and mugwort (Artemisia vulgaris) during sampling A.

\begin{tabular}{|c|c|c|c|c|c|c|}
\hline \multirow[b]{2}{*}{ Host plant } & \multirow[b]{2}{*}{ Region } & \multirow[b]{2}{*}{ Location } & \multirow[b]{2}{*}{ Winter } & \multirow[b]{2}{*}{$n$} & \multicolumn{2}{|c|}{ ‘Traditional’ parasitism (\%) } \\
\hline & & & & & Tachinids & M. cingulum \\
\hline \multirow[t]{55}{*}{ Z. mays } & \multirow[t]{4}{*}{ Midi-Pyrénées } & Muret $^{*}$ & 2002-03 & 117 & 3.42 & 0 \\
\hline & & Fiac & 2003-04 & 97 & 4.12 & 0 \\
\hline & & Bérat & 2004-05 & 148 & 0 & 0 \\
\hline & & Poucharramet & 2004-05 & 124 & 3.23 & 0 \\
\hline & \multirow[t]{4}{*}{ Aquitaine } & Castel Sarrazin* & 2002-03 & 77 & 5.19 & 0 \\
\hline & & Heugas Eple & 2003-04 & 140 & 2.86 & 0 \\
\hline & & & 2004-05 & 159 & 0.63 & 0 \\
\hline & & Civrac sur Dordogne & 2004-05 & 196 & 10.71 & 0 \\
\hline & \multirow[t]{3}{*}{ Poitou-Charentes } & Tuzie $^{\star}$ & 2002-03 & 100 & 6.00 & 0 \\
\hline & & Chadurie & 2003-04 & 156 & 0.64 & 0 \\
\hline & & Linazay & 2004-05 & 100 & 4.00 & 0 \\
\hline & \multirow[t]{3}{*}{ Rhône-Alpes } & Beaupont* & 2002-03 & 216 & 2.78 & 0 \\
\hline & & & 2003-04 & 118 & 0 & 0 \\
\hline & & Pirajoux & $2004-05$ & 162 & 4.94 & 0 \\
\hline & \multirow[t]{3}{*}{ Pays de la Loire } & Marolle les Brault et Monhoudou* & $2002-03$ & 124 & 0 & 0 \\
\hline & & Grues & 2003-04 & 123 & 4.07 & 0 \\
\hline & & Doué la Fontaine & 2004-05 & 152 & 7.24 & 0 \\
\hline & \multirow[t]{3}{*}{ Auvergne } & \multirow[t]{3}{*}{ Escurolles $^{\star}$} & 2002-03 & 71 & 0 & 0 \\
\hline & & & 2003-04 & 134 & 0.75 & 0 \\
\hline & & & 2004-05 & 137 & 0 & 0 \\
\hline & \multirow[t]{3}{*}{ Île-de-France } & Neauphle le vieux & $2002-03$ & 19 & 0 & 0 \\
\hline & & Maisoncelles en Brie & 2003-04 & 94 & 0 & 0 \\
\hline & & Chaumes en Brie & 2004-05 & 126 & 0 & 0 \\
\hline & \multirow[t]{7}{*}{ Bourgogne } & Baignant & 2002-03 & 31 & 0 & 0 \\
\hline & & Allerey sur Saône & 2002-03 & 139 & 0 & 0 \\
\hline & & & 2003-04 & 91 & 0 & 0 \\
\hline & & & 2004-05 & 177 & 3.95 & 0 \\
\hline & & Flogny La Chapelle & $2002-03$ & 33 & 0 & 0 \\
\hline & & & 2004-05 & 47 & 0 & 0 \\
\hline & & Marigny les Reullee & 2003-04 & 121 & 0 & 0 \\
\hline & \multirow[t]{5}{*}{ Franche-Comté } & Chenevrey $^{\star}$ & 2002-03 & 26 & 0 & 0 \\
\hline & & La Loye & 2003-04 & 152 & 0 & 0 \\
\hline & & & $2004-05$ & 132 & 1.52 & 0 \\
\hline & & Asnans & $2003-04$ & 159 & 1.26 & 0 \\
\hline & & & 2004-05 & 100 & 2.00 & 0 \\
\hline & Lorraine & Château-Salins* & 2002-03 & 129 & 3.88 & 0 \\
\hline & & Laître-sous-Amance ${ }^{*}$ & 2002-03 & 118 & 4.24 & 0 \\
\hline & & Ménil sur Saulx* & 2002-03 & 107 & 0 & 0 \\
\hline & & Lixheim & 2004-05 & 138 & 0 & 0 \\
\hline & Champagne-Ardenne & Le Thour & 2003-04 & 118 & 0.85 & 0 \\
\hline & & & 2004-05 & 129 & 2.33 & 0 \\
\hline & Picardie & Saint Martin Longueau* & 2002-03 & 69 & 1.45 & 0 \\
\hline & & Le Bosquel-Conty & 2003-04 & 108 & 0 & 0 \\
\hline & & Crèvecoeur le Grand & $2004-05$ & 62 & 0 & 0 \\
\hline & Haute-Normandie & Andé* & 2002-03 & 111 & 0 & 0 \\
\hline & & & 2003-04 & 112 & 3.57 & 0 \\
\hline & Alsace & Waltenheim & 2002-03 & 77 & 0 & 0 \\
\hline & & Hohengoeft & 2002-03 & 79 & 0 & 0 \\
\hline & & & 2004-05 & 118 & 0 & 0 \\
\hline & & Wiwersheim & 2002-03 & 74 & 0 & 0 \\
\hline & & & 2003-04 & 122 & 0 & 0 \\
\hline & & Fessenheim & 2002-03 & 108 & 0 & 0 \\
\hline & & & 2003-04 & 138 & 0 & 0 \\
\hline & & & 2004-05 & 168 & 0 & 0 \\
\hline & & Ferrette & 2002-03 & 99 & 0 & 0 \\
\hline
\end{tabular}


Table 1 (Continued).

\begin{tabular}{|c|c|c|c|c|c|c|}
\hline \multirow[b]{2}{*}{ Host plant } & \multirow[b]{2}{*}{ Region } & \multirow[b]{2}{*}{ Location } & \multirow[b]{2}{*}{ Winter } & \multirow[b]{2}{*}{$n$} & \multicolumn{2}{|c|}{ 'Traditional' parasitism (\%) } \\
\hline & & & & & Tachinids & M. cingulum \\
\hline & & Meistratzheim & 2003-04 & 102 & 0 & 0 \\
\hline & & Gambsheim & 2003-04 & 134 & 5.22 & 0 \\
\hline & & & 2004-05 & 167 & 4.79 & 0 \\
\hline & & Sélestat & 2004-05 & 138 & 11.59 & 0 \\
\hline & PACA & Mollégès & 2003-04 & 101 & 2.97 & 0 \\
\hline & & & $2004-05$ & 146 & 8.90 & 0 \\
\hline & Limousin & St Pantaléon de Larche & 2003-04 & 174 & 0 & 0 \\
\hline & & St Cyr la Roche & 2004-05 & 142 & 11.27 & 0 \\
\hline & Bretagne & Taupont & 2004-05 & 73 & 1.37 & 0 \\
\hline \multirow[t]{7}{*}{ A. vulgaris } & Nord-Pas-de-Calais & Lesquin & 2002-03 & 99 & 1.01 & 29.29 \\
\hline & & Feuchy & 2002-03 & 100 & 0 & 0 \\
\hline & Picardie & Roye & 2002-03 & 100 & 0 & 7.00 \\
\hline & & Beauvais & 2002-03 & 142 & 0 & 0 \\
\hline & & Verberie & 2002-03 & 23 & 0 & 34.78 \\
\hline & Île-de-France & Grignon & 2002-03 & 149 & 0 & 19.46 \\
\hline & Centre & Meung sur Loire & 2002-03 & 114 & 0 & 22.81 \\
\hline
\end{tabular}

These rates were estimated by counting the number of tachinid pupae (Lydella thompsoni and Pseudoperichaeta nigrolineata were pooled because their pupal stages could not be distinguished) and of cocoons of Macrocentrus cingulum among the total number of living larvae (n) placed under diapause-breaking conditions after completion of diapause in the laboratory.

*Data for L. thompsoni and P. nigrolineata parasitism in these populations have been previously reported in Agustì et al. (2005). A subsample of these populations has also been analysed using the molecular method (Table 4).

Table 2 Parasitism rates in Ostrinia sp. populations collected on maize, mugwort and hop (sample B), as estimated by molecular detection ( $n$, number of diapausing larvae analysed).

\begin{tabular}{|c|c|c|c|c|c|c|c|c|}
\hline \multirow[b]{2}{*}{ Region } & \multirow[b]{2}{*}{ Location } & \multirow[b]{2}{*}{ Winter } & \multirow[b]{2}{*}{ Host-plant } & \multirow[b]{2}{*}{$n$} & \multicolumn{4}{|c|}{ 'Molecular' parasitism rate (\%) } \\
\hline & & & & & L. thompsoni & P. nigrolineata & M. cingulum & Microsporidia \\
\hline \multirow{2}{*}{$\begin{array}{l}\text { Nord-Pas- } \\
\text { de-Calais }\end{array}$} & Wailly lès & 2005-2006 & Artemisia vulgaris & 59 & 0 & 0 & 20.34 & 0 \\
\hline & Arras & 2005-2006 & Zea mays & 46 & 0 & 0 & 0 & 2.17 \\
\hline \multirow[t]{3}{*}{ Picardie } & Boves & 2005-2006 & A. vulgaris & 56 & 23.21 & 0 & 50.00 & 75.0 \\
\hline & & 2005-2006 & Humulus lupulus & 45 & 0 & 0 & 11.11 & 2.22 \\
\hline & & 2005-2006 & Z. mays & 52 & 3.85 & 0 & 0 & 82.69 \\
\hline \multirow[t]{3}{*}{ Île-de-France } & Thiverval - Grignon & 2004-2005 & A. vulgaris & 56 & 0 & 0 & 25.00 & 1.79 \\
\hline & - Gambais & 2005-2006 & H. lupulus & 45 & 0 & 0 & 13.33 & 0 \\
\hline & - Jouars - St Quentin & 2004-2006 & Z. mays & 91 & 3.30 & 0 & 1.10 & 2.20 \\
\hline \multirow[t]{2}{*}{ Rhône-Alpes } & Châteauneuf sur Isère & 2005-2006 & H. lupulus & 35 & 0 & 0 & 5.71 & 0 \\
\hline & & 2005-2006 & Z. mays & 69 & 2.90 & 0 & 0 & 15.94 \\
\hline \multirow[t]{2}{*}{ Aquitaine } & Granges sur Lot & 2005-2006 & H. lupulus & 58 & 1.72 & 0 & 0 & 5.17 \\
\hline & & 2005-2006 & Z. mays & 55 & $3.70(n=54)$ & $5.56(n=54)$ & 1.82 & $35.19(n=54)$ \\
\hline \multirow[t]{2}{*}{ Midi-Pyrénées } & Lagardelle sur Lèze & 2005-2006 & H. lupulus & 54 & 0 & 1.85 & 0 & 0 \\
\hline & & 2005-2006 & Z. mays & 53 & 0 & 1.89 & 0 & 3.77 \\
\hline
\end{tabular}

35 individuals of this species collected across its range (Table 3), using the universal primers Lcol490 and Hco2198 (Folmer et al., 1994). We conducted PCR in $25 \mu \mathrm{L}$ containing $12.5 \mu \mathrm{L}$ of Taq PCR Master Mix (Qiagen), $11 \mu \mathrm{L}$ of $\mathrm{H}_{2} \mathrm{O}, 1 \mu \mathrm{L}$ of DNA, and a final concentration of $0.5 \mu \mathrm{m}$ of each primer. The PCR included a denaturation step at $95{ }^{\circ} \mathrm{C}$ for $2 \mathrm{~min}$ followed by 35 cycles of: $95{ }^{\circ} \mathrm{C}, 1 \mathrm{~min} ; 40{ }^{\circ} \mathrm{C}, 1 \mathrm{~min}$ and $72{ }^{\circ} \mathrm{C}, 1.5 \mathrm{~min}$, and a final elongation at $72{ }^{\circ} \mathrm{C}$ for $7 \mathrm{~min}$.
Sequencing of PCR products (Genome Express, Meylan, France) yielded eight haplotypes (Genbank, FJ617011 to FJ617018), based on which we designed a pair of specific forward (FMl: 5'-CCTCCGTTATCATTAAATATTAGAC) and reverse (RMl: 5'-AAAATAGCAGTAATTAAAATA GATCA) primers amplifying a 184-bp fragment. These primers differ from O. nubilalis (Genbank: AY649321), P. nigrolineata (Genbank: AY649320) and L. thompsoni (Genbank: AY649319) COI sequences and we checked that there was no cross amplification with these species. 
Table 3 Origin of the parasite specimens used for designing the molecular markers and as positive polymerase chain reaction controls.

\begin{tabular}{|c|c|c|c|c|c|}
\hline \multirow[b]{2}{*}{ Parasite } & \multicolumn{5}{|c|}{ Characteristics of the Ostrinia samples from which the parasites were recovered } \\
\hline & $n$ & Country & Location & Host-plant & Collector \\
\hline \multirow[t]{4}{*}{$\begin{array}{l}\text { Lydella } \\
\text { thompsoni }\end{array}$} & One adult & France & Castillon Savès, Midi-Pyrénées & Z. mays & $\begin{array}{l}\text { Service Régional de Protection } \\
\text { des Végétaux, Haute-Garonne, } \\
\text { France }\end{array}$ \\
\hline & Two adults & France & Pamiers, Midi-Pyrénées & Z. mays & The authors \\
\hline & One adult & France & Bérat, Midi-Pyrénées & Z. mays & The authors \\
\hline & Two adults & France & Chis, Aquitaine & Z. mays & The authors \\
\hline $\begin{array}{l}\text { Pseudoperichaeta } \\
\text { nigrolineata }\end{array}$ & One adult & France & Saint Clar, Midi-Pyrénées & Z. mays & $\begin{array}{l}\text { Service Régional de Protection } \\
\text { des Végétaux, Haute-Garonne, } \\
\text { France }\end{array}$ \\
\hline \multirow{7}{*}{$\begin{array}{l}\text { Macrocentrus } \\
\text { cingulum }\end{array}$} & Five cocoons & France & Paris, lle de France & A. vulgaris & The authors \\
\hline & Six cocoons & France & Lille, Nord Pas de Calais & A. vulgaris & The authors \\
\hline & One cocoon & France & Amiens, Picardie & A. vulgaris & The authors \\
\hline & Five cocoons & Germany & Kropp, Schleswig-Holstein & A. vulgaris & $\begin{array}{l}\text { V. Calcagno, T. Malausa and } \\
\text { the authors }\end{array}$ \\
\hline & Six cocoons & Japan & Kannondai, Ibaraki & S. italica & L. Pélozuelo \\
\hline & Five adults & China & Beijing, Hebei & Z. mays & $\begin{array}{l}\text { K. He and Z. Wang, Chinese Academy } \\
\text { of Agricultural Sciences (Beijing, China) }\end{array}$ \\
\hline & Seven adults & $\begin{array}{l}\text { United } \\
\text { States }\end{array}$ & Rosemount, Minnesota & Z. mays & $\begin{array}{l}\text { C. Hsu and G. Heimpel, U. Minnesota } \\
\text { (St. Paul, USA) }\end{array}$ \\
\hline Microsporidia & 17 Larvae & France & Poucharramet, Midi-Pyrénées & Z. mays & $\begin{array}{l}\text { Service Régional de Protection des } \\
\text { Végétaux, Haute-Garonne, France }\end{array}$ \\
\hline
\end{tabular}

n, number of individuals. Ostrinia host plants were maize (Z. Mays), mugwort (A. vulgaris) and foxtail millet (Setaria italica L. P. Beauv.).

Table 4 Parasitism, as estimated by molecular detection, in a subsample of diapausing larvae collected in winter 2002-2003 and frozen directly after collection (i.e. without completion of diapause) of a subset of the Ostrinia populations listed in Table 1.

\begin{tabular}{|c|c|c|c|c|c|c|c|}
\hline \multirow[b]{2}{*}{ Host-plant } & \multirow[b]{2}{*}{ Region } & \multirow[b]{2}{*}{ Location } & \multirow[b]{2}{*}{$n$} & \multicolumn{4}{|c|}{ 'Molecular' parasitism rate (\%) } \\
\hline & & & & L. thompsoni & P. nigrolineata & $\begin{array}{l}\text { Macrocentrus } \\
\text { cingulum }\end{array}$ & Microsporidia \\
\hline \multirow[t]{12}{*}{ Zea mays } & Midi-Pyrénées & Muret* & 50 & 0 & 0 & 30.00 & $20.40(n=49)$ \\
\hline & Aquitaine & Castel Sarrazin* & 50 & 4.00 & 8.00 & 18.00 & 2.00 \\
\hline & Poitou-Charentes & Tuzie* $^{*}$ & 50 & 4.00 & 0 & 26.00 & 2.00 \\
\hline & Rhône-Alpes & Beaupont* & 50 & 6.00 & 10.00 & 0 & 0 \\
\hline & Pays de la Loire & $\begin{array}{l}\text { Marolles les Brault } \\
\text { et Monhoudou* }\end{array}$ & 50 & 0 & 0 & 0 & 4.00 \\
\hline & Auvergne & Escurolles* & 50 & 0 & 0 & 28.00 & 0 \\
\hline & Lorraine & Château-Salins* & 50 & 4.00 & 4.00 & 0 & $2.08(n=48)$ \\
\hline & & Laître-sous-Amance* & 50 & 4.00 & 8.00 & 0 & 0 \\
\hline & & Ménil sur Saulx* & 50 & 0 & 4.00 & 0 & 0 \\
\hline & Picardie & Saint-Martin Longueau* & 50 & 0 & 0 & 0 & 2.00 \\
\hline & Haute-Normandie & Andé* & 50 & 4.00 & 0 & 2.00 & 2.00 \\
\hline & Franche-Comté & Chenevrey* & 50 & 0 & 0 & 0 & 2.00 \\
\hline \multirow{6}{*}{$\begin{array}{c}\text { Artemisia } \\
\text { vulgaris }\end{array}$} & Nord-Pas-de-Calais & Lesquin & 50 & 2.00 & 0 & 70.0 & 8.00 \\
\hline & & Feuchy & 49 & 0 & 0 & 0 & 0 \\
\hline & Picardie & Roye & 49 & 0 & 0 & 30.61 & 0 \\
\hline & & Beauvais & 50 & 4.00 & 0 & 22.00 & 0 \\
\hline & Île-de-France & Grignon & 48 & 4.17 & 0 & 58.33 & 0 \\
\hline & Centre & Meung sur Loire & 40 & 0 & 0 & 85.00 & 0 \\
\hline
\end{tabular}

$n$, Number of diapausing larvae analysed (unless stated otherwise for one particular parasite in the relevant column: indeed, it happened occasionally that the amount of DNA was not sufficient to conduct analyses for all four parasites).

*Data for Lydella thompsoni and Pseudoperichaeta nigrolineata parasitism in these populations have been previously reported in Agustì et al. (2005). 
To evaluate our ability to accurately assess parasitism rates by $M$. cingulum with FMl and RMl, we artificially 'contaminated' $O$. nubilalis DNA extracts with $M$. cingulum DNA extracts at various ratios $(1 / 10,1 / 100$ or $1 / 1000)$ to mimic what is to be expected in a DNA extract of a parasitized larva.

The PCR conditions were as with Lcol490/Hco2198, except for annealing temperature $\left(50{ }^{\circ} \mathrm{C}\right)$. PCR products were separated by electrophoresis on a $2.5 \%$ agarose gel stained with ethidium bromide. Those PCR yielded positive results for $M$. cingulum and 'artificially contaminated' $O$. nubilalis extracts at all ratios, and gave negative results for $O$. nubilalis, $P$. nigrolineata and L. thompsoni extracts. We thus subsequently used FMl/RMl for molecular detection of $M$. cingulum in Ostrinia larvae (Tables 2 and 4). All PCR amplifications included a negative and a positive control.

\section{Molecular detection of microsporidia}

To detect possible microsporidia infections, we carried out PCR on DNA extracts of Ostrinia larvae using a primer set (Vlf: forward, 5'-CACCAGGTTGATTCTGCCTGAC, Weiss et al. (1994) and 530r: reverse, 5'-CCGCGG CTGCTGGCAC, Ironside et al. (2003) adapted from Baker et al. (1995)) amplifying a c. 440-bp region of the small subunit (SSU) rDNA which is extremely conserved among microsporidia species.

We conducted PCR in $10 \mu \mathrm{L}$ containing $1 \times$ PCR buffer, dNTP (0.25 mm each), I U Taq-polymerase (Qiagen), and $1 \mu \mathrm{M}$ of each primer. PCR comprised 30 cycles of: $92{ }^{\circ} \mathrm{C}, 30 \mathrm{~s} ; 65^{\circ} \mathrm{C}, 30 \mathrm{~s}$ and $72{ }^{\circ} \mathrm{C}, 1 \mathrm{~min}$. Conditions for initial denaturation were $92{ }^{\circ} \mathrm{C}$ for $3 \mathrm{~min}$, and were $72{ }^{\circ} \mathrm{C}$ for $10 \mathrm{~min}$ for the final extension step. We separated PCR products by electrophoresis in $2 \%$ agarose gels stained with ethidium bromide.

\section{Levels of parasitism}

For a 40-50 individual subsample of certain populations of sample A (Table 4) and for all populations of sample B (Table 2) - all frozen at $-20{ }^{\circ} \mathrm{C}$ directly after collection or reception - we carried out PCR to detect the presence of $L$. thompsoni, $P$. nigrolineata, $M$. cingulum and microsporidia. For each parasite and Ostrinia population, we calculated the percentage of parasitism at the beginning of the winter diapause as the ratio of Ostrinia larvae that gave a 'positive' amplification signal over the total number of larvae screened by PCR.

All remaining larvae of sample A (Table 1) were used to estimate the mean percentage of parasitism after diapause completion, i.e. the 'traditional' method for studying parasitism. To allow completion of diapause, we maintained larvae at $8{ }^{\circ} \mathrm{C}$ in complete darkness for 3 months. We then counted and discarded dead larvae (mean \pm SE: $44.6 \pm 16.6 \%$ of each population). Between
19 and 216 larvae per population were still alive, or 8186 individuals. To break diapause, we placed survivors at $25{ }^{\circ} \mathrm{C}$, under a 16:8 h light:dark (L:D) photoperiod, with a moistened piece of cotton (Grenier et al., 1990). Within 3 weeks, all Ostrinia larvae reached pupation, turned into a tachinid pupa or a braconid cocoon, or died for an unknown reason. For each population and each parasitoid, we calculated percentages of parasitism at the end of the winter diapause as the ratio of pupae (for Tachinids) or cocoons (for $M$. cingulum) over the total number of Ostrinia larvae placed in diapause-breaking conditions, i.e. by the number of larvae that had survived the winter.

\section{Statistical analysis}

Within each of the two datasets obtained by the molecular (Tables 2 and 4) and by the traditional (Table 1) method, we compared the percentages of parasitism between host plants by fitting a logistic regression model by maximum likelihood with 'host plant' as a fixed effect and 'locality' as a random effect, using the lmer package in $\mathrm{R}$ (Bates \& Maechler, 2009) and 'probit' as a link function. We considered each parasite separately, as well as the overall level of parasitism. In order to test whether the traditional and molecular methods measured the same or different phenomena, i.e. whether lower emergence of parasitoids was due to lack of parasitism or larval mortality of parasitoids on one or both hosts, we tested for differences between the two methods for populations listed in Table 4 by fitting a logistic regression model by maximum likelihood with 'host plant', 'method' and their interaction as fixed effects, using the lmer package in R (Bates \& Maechler, 2009) and 'probit' as a link function. As sample sizes were usually unbalanced, we tested each effect by controlling for all other factors (Type II ANOVA). We conducted all statistical analyses with $\mathrm{R}$ software ( $\mathrm{R}$ Development Core Team, 2007).

\section{Results}

\section{Levels of parasitism in sample A}

The two tachinid flies L. thompsoni and P. nigrolineata, and the braconid wasp $M$. cingulum were, as expected (Thompson \& Parker, 1928), by far the major parasitoids infesting diapausing Ostrinia larvae. The traditional method revealed additional hymenopteran parasitoids: the ichneumonids Sinophorus turionus Ratzeburg, Diadegma fenestralis Holmgren, Eriborus terebrans Gravenhorst (also known as Diadegma terebrans Momoi) and Pristomerus sp., the braconids Microgaster tibialis Nees, Bracon brevicornis Wesmaet, Apanteles sp., and the pteromalid Trichomalopsis sp. However, they were always extremely rare $(<1 \%$ in all populations). Thompson $\delta$ Parker's (1928) comprehensive study on European Ostrinia also indicates that egg and pupal parasitoids are few 
and typically cause but low rates of parasitism. Nevertheless, as our study was conducted on larvae collected in autumn, it must be acknowledged that it excludes parasites of earlier or later stages, as well as those possibly infesting only the first annual Ostrinia generation in bivoltine zones.

Across years and space, Ostrinia populations of sample A showed clear, host-plant-related differences in the rate of parasitism by the three predominant parasitoids. Indeed, whereas mortality rates from unknown reasons were similar (mean \pm SE: $42.6 \pm 5.3 \%$ in mugwort-collected populations vs. $35.8 \pm 1.6 \%$ in maize-collected ones; $\chi^{2}=1.54$, d.f. $=1, P=0.214$ ), parasitism rates at the end of the winter diapause estimated by the traditional method were c. 8 times higher in mugwort-collected than in maize-collected populations (Table 1 , mean $\pm \mathrm{SE}$ : $16.3 \pm 5.4 \% \quad$ vs. $2.1 \pm 0.4 \% ; \quad \chi^{2}=9.51, \quad$ d.f. $=1$, $P=0.002$ ). Parasitism rates at the beginning of the winter diapause estimated by the molecular method showed the same trend, though they differed only by a factor 3 (Table 4 , mean \pm SE: $45.7 \pm 13.1 \%$ vs. $15.7 \pm 4.1 \%$; $\chi^{2}=83.22$, d.f. $\left.=1, P<0.0001\right)$.

This difference in parasitism rates was mostly because of $M$. cingulum. Indeed, over all years and locations, not a single $M$. cingulum was found emerging from 7459 larvae collected from 64 populations on maize, whereas a substantial number of cocoons of this species were recovered from five of the seven populations collected in mugwort (Table 1). Hence, the traditional method revealed a significant difference in the rate of $M$. cingulum emerging after diapause from Ostrinia collected on the two host plants (Table 1 , mean \pm SE: $16.2 \pm 5.3 \%$ vs. $0 \% ; \quad \chi^{2}=9.53$, d.f. $\left.=1, \quad P=0.002\right)$. The molecular method confirmed that $M$. cingulum DNA was detected much more frequently in mugwort-collected than in maize-collected populations at the beginning of diapause
(Table 4 , mean \pm SE: $44.3 \pm 13.1 \% \quad$ vs. $\quad 8.7 \pm 3.7 \%$; $\chi^{2}=88.49$, d.f. $\left.=1, P<0.0001\right)$.

In contrast to $M$. cingulum, parasitism by tachinids was higher on maize than on mugwort (Table 1 , mean \pm SE: $2.1 \pm 0.4 \% \quad$ vs. $\quad 0.1 \pm 0.1 \% ; \quad \chi^{2}=7.35, \quad$ d.f. $=1$, $P=0.006632)$. The molecular method showed a complete absence of $P$. nigrolineata on mugwort but not on maize (Table 4, mean \pm SE: $2.8 \pm 1.1 \%$ vs. $0 \%$; $\chi^{2}=2.38$, d.f. $\left.=1, P=0.305\right)$ and a higher L. thompsoni infestation rates on maize than on mugwort (Table 4, mean \pm SE: $2.2 \pm 0.7 \%$ vs. $\quad 1.7 \pm 0.8 \% ; \quad \chi^{2}=15.21$, d.f. $=1, P<0.001)$. Regardless of method, the estimate of overall parasitism by Tachinids was usually low $(<10 \%$ for $P$. nigrolineata and $<6 \%$ for L. thompsoni, Table 4 ), so that they contributed less to total parasitism than $M$. cingulum.

Finally, microsporidia - which were studied only by means of the molecular method - were also more abundant in populations collected on maize than on mugwort (Table 4, mean \pm SE: $\quad 3.0 \pm 1.6 \%$ vs. $1.3 \pm 1.3 \% ; \chi^{2}=109.56$, d.f. $\left.=1, P<0.0001\right)$. However, they were absent in $50 \%$ of the population samples and occurred at low rates $(<8 \%$ except in one population where it reached $20 \%$ ) in the remaining population samples.

Noteworthy, M. cingulum parasitism was much higher when estimated by the molecular than by the traditional method, and the size of this effect was significantly higher on mugwort than on maize (method: $\chi^{2}=263.32$, d.f. $=1, \quad P<0.0001$; plant:method interaction: $\chi^{2}=$ 20.40 , d.f. $=1, P<0.0001$, Fig. 2 ). The molecular method also yielded higher estimates than the traditional method for Tachinids, but in this case the size of the effect did not differ according to host plant (method: $\chi^{2}=24.13$, d.f. $=1, \quad P<0.0001$; plant:method interaction: $\chi^{2}<$ 0.0001 , d.f. $=1, P=0.999$; Fig. 2 ).
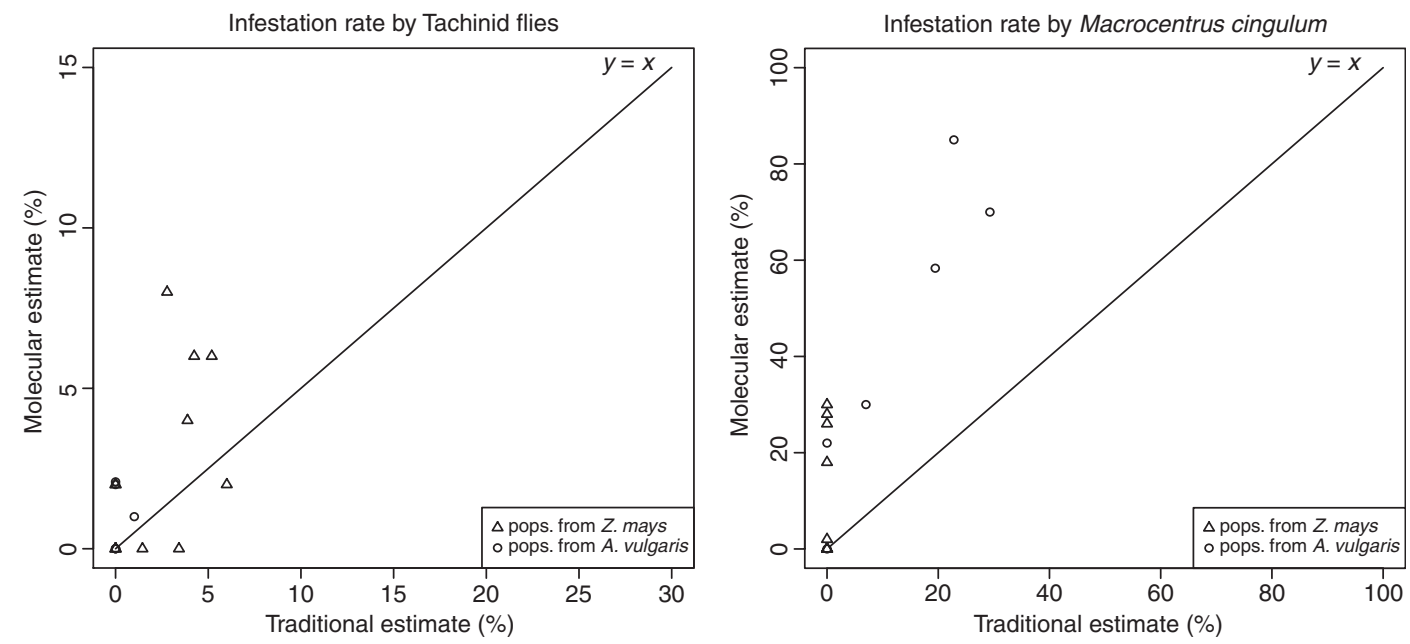

Fig. 2 Traditional vs. molecular estimates of parasitism rates by Tachinids and by Macrocentrus cingulum. Data points situated above the $y=x$ line correspond to molecular estimates that were larger than traditional ones. 


\section{Levels of parasitism in sample B}

The differences we found in sample A between Ostrinia populations collected from maize and mugwort, notably with respect to $M$. cingulum and $P$. nigrolineata infestations, could be due to differences in host plant, but also to differences in adult parasitoid density between locations and years. Therefore, we decided to examine pairs or triplets of Ostrinia populations collected on different host plants in the same location $(<2 \mathrm{~km}$ apart) and at the same time (sample B; Table 2).

Consistently with results obtained for sample A, $M$. cingulum DNA was again detected in populations collected on mugwort much more frequently $(20-50 \%)$ than in sympatric populations collected on maize (only one infested larva in samples of three populations with c. 50 individuals each). P. nigrolineata was absent in most locations and L. thompsoni infestation rates remained low in all populations (Table 2). Like sample A, sample B showed higher microsporidia infestation rates in maizecollected than in mugwort-collected population samples (Table 2). An influence of locality on microsporida infection rates cannot be excluded, considering the fact that in Boves, Ostrinia larvae were highly infested by microsporidia on both maize (c. 83\%) and mugwort $(75 \%)$.

Parasitism rates on hop were estimated in too few populations to draw any firm conclusions. However, $M$. cingulum infestation rates were lower in hop than in mugwort in both places where sympatric populations were sampled on the two plants, and higher in hop than in maize in three of four places where it was present in sympatric populations sampled on the two plants.

\section{Discussion}

Ecological speciation by host shift in phytophagous insects (Howard \& Berlocher, 1998; Drès \& Mallet, 2002) involves adaptation to a new host plant and genetic differentiation between an ancestral taxon feeding on the original host plant(s) and a derived taxon feeding on the new one. The initial fitness cost of shifting to a new plant species is reduced - and thus the shift is facilitated - if the new plant offers EFS (Jeffries \& Lawton, 1984; Ode, 2006), i.e. if natural enemies cause a significantly stronger fitness reduction to individuals feeding on the original host plant(s) [condition (1) in Berdegue et al. (1996)] than to those feeding on the new plant [condition (2) in Berdegue et al. (1996)]. Such a situation can notably arise when the new host is a recently introduced plant species - such as maize in Europe - as it may then be less protected from phytophagous insects by co-adapted natural enemies (review in Price et al., 1980; Gratton \& Welter, 1999; Chen \& Welter, 2007).
In the present study, Ostrinia larvae entering diapause were highly parasitized when collected on mugwort, and 2-3 times less so when collected on maize (molecular estimates: $46 \%$ vs. $16 \%$ when considering sample A alone and $45 \%$ vs. $21 \%$ when pooling samples A and B). In addition, the maize-collected larvae showed an 8 times lower post-diapause mortality because of parasitoid emergence than the mugwort-collected ones (sample A, $16 \%$ vs. $2 \%$ ).

The higher parasitism and parasitoid-related mortality in mugwort-collected Ostrinia larvae were mainly because of $M$. cingulum, which caused the largest part of infestation (up to $85 \%$ ) and of post-diapause mortality (up to $35 \%$ ) in these populations. In contrast, M. cingulum was absent (according to the traditional method) or present at lower rates (according to the molecular method) in populations feeding on maize. The higher infestation of populations collected on maize by tachinids and microsporidia was not sufficient to offset the higher $M$. cingulum infestation of populations collected on mugwort.

Altogether, our data therefore show that M. cingulum causes a substantial mortality on mugwort and hop (which are believed to be $O$. scapulalis' 'original' host plants), and that both parasitism and post-diapause parasitoid-caused mortality are significantly lower in O. nubilalis populations collected on maize, the recently introduced host. Several proximal mechanisms by which a plant can protect insects against parasites - and hence provide EFS - have been documented (Price et al., 1980).

Firstly, they include mechanisms causing lower oviposition. Indeed, (i) maize stalks have a larger diameter than most mugwort stalks. Although apparently $M$. cingulum does not sting through the stalk (Parker, 1931; Edwards \& Hopper, 1998), this difference in host plant structure could prevent oviposition, as shown for apple vs. hawthorn fruit in the case of the fly $R$. pomonella (Feder, 1995), wild vs. cultivated sunflower seeds for the sunflower moth Homoeosoma electellum (Chen \& Welter, 2007), or Physalis fruit for two heliothine moth species (Sisterson \& Gould, 1999; Oppenheim \& Gould, 2002). (ii) Mugwort plants grow in denser stands than maize and White \& Andow (2005) found evidence that $M$. cingulum infestation may increase with plant density. (iii) Maize (Lupolli et al., 1990; Schnee et al., 2006) and mugwort (Barney et al., 2005) emit distinct volatiles whereas female $M$. cingulum are attracted to certain plant volatiles more than others (Ding et al., 1989a,b; Udayagiri \& Jones, 1993; Jones, 1996).

Secondly, after oviposition, the parasitoid's development success may vary with host plant. Indeed, $M$. cingulum DNA was detected in a significantly higher fraction of Ostrinia larvae than the fraction that died and turned into a $M$. cingulum cocoon after diapause. This discrepancy was observed in samples collected from mugwort (44\% vs. 16\%) but it was particularly striking in those collected from maize ( $9 \%$ vs. $0 \%)$. Over all years and locations, not a single $M$. cingulum adult was 
observed emerging from 7459 larvae collected from maize in 3 years and 64 populations, whereas five in 12 of these populations showed positive PCR signals corresponding to $2-30 \%$ infestation by $M$. cingulum. Plant chemicals may affect the parasitoid via the insect host (Denno et al., 1990; Turlings \& Benrey, 1998; Singer et al., 2004). For instance, DIMBOA (2,4-dihydroxy-7methoxy-1,4-benzoaxin-3-one), which is produced by maize, has been shown to influence the development of the parasitoid D. terebrans (Hymenoptera: Ichneumonidae) in O. nubilalis (Campos et al., 1990). Although this influence was positive for DIMBOA and D. terebrans, it may be negative for other plant-produced chemical substances and/or for $M$. cingulum.

However, differences in $M$. cingulum oviposition and/or survival could also result from genetic differences between $O$. scapulalis and $O$. nubilalis, rather than or in addition to resulting directly from the host plants on which they feed. For instance, maize may have shifted the phenology of $O$. nubilalis (Thomas et al., 2003 but see Malausa et al., 2005) to a time window that for some reason is less favourable for oviposition by $M$. cingulum. Similarly, $O$. nubilalis may be better protected than $O$. scapulalis by its immune system. The closely related $O$. furnacalis, which is also under attack by $M$. cingulum in Asia, is, to some extent, able to prevent the parasitoid's development by encapsulating the embryo in a layer of specialized hemocytes (Hu et al., 2003). This immune defence mechanism may perform better in one than in the other European Ostrinia species. At least one other set of closely related but genetically differentiated taxa displays such genetically based difference in immune defences [i.e. Pieris rapae vs. P. melete and P. napi (Ohsaki \& Sato, 1990)]. In our case, this would however raise the question of how low resistance is maintained in $O$. scapulalis despite ongoing gene flow (Malausa et al., 2005) between the two Ostrinia species and strong selection pressure exerted by $M$. cingulum.

In sum, whereas our data clearly show that parasitism by $M$. cingulum is lower in Ostrinia larvae feeding on maize than in those feeding on mugwort, the mechanistic explanation of this difference is an open question. We see no strong evidence in our data or elsewhere indicating which is(are) the best candidate(s), so that only empirical studies can tell. From an evolutionary perspective, it will be interesting to focus specifically on assessing the relative importance of factors resulting directly from the plant vs. factors resulting from genetic differences between the two insect hosts. Indeed, the possibility that genetic differences involved in divergent adaptation to different host plants and reduction of gene flow are also involved - be it directly, by drift, genetic linkage or pleiotropy - in differences in resistance to parasitoids offers an interesting perspective on how protection from parasites may result from EFS on an ecological timescale and from ecological speciation on an evolutionary timescale.
Whether the divergence between the two sibling species $O$. scapulalis and $O$. nubilalis in Europe is really due to ecological speciation on distinct host plants and, if so, whether the introduction of maize triggered this speciation is still under debate (Malausa et al., 2007b). However, within such a scenario, how important may EFS have been for the adaptation of $O$. nubilalis to maize and its divergence from $O$. scapulalis? Berdegue et al. (1996) argue that EFS is crucial when fitness is higher on the original than on the alternative host plant in the absence of natural enemies [condition (3) in Berdegue et al. (1996)]: in such case, EFS may make the difference by offsetting this initial fitness cost. Calcagno et al. (2007) found contrasting results with respect to condition (3) in Ostrinia: in a greenhouse experiment, $O$. scapulalis survived better on maize than on mugwort, but in a more realistic field experiment protected by an insect-proof net, it was the opposite. Thus, at least under certain circumstances, maize is, per se, a poorer resource than mugwort for $O$. scapulalis, so that the presence of natural enemies and maize providing EFS may have been key to permitting the host shift. By protecting Ostrinia larvae from their main parasitoid, $M$. cingulum, maize may thus have favoured the evolution of a species that then became one of its worst enemies around the world.

\section{Acknowledgments}

The authors thank A. Loiseau for her help in designing the primers, G. Heimpel, C. Hsu, L. Pélozuelo, K. He and Z. Wang for providing Macrocentrus cingulum samples, J.-B. Ferdy, C. Andalo and P. Blanchard for their help in statistical analyses, and the Services Régionaux de Protection des Végétaux and V. Calcagno for their help with sampling. This study was supported by CNRS grant PICS 3864, by an Action Ponctuelle de Coopération of University P. Sabatier, by the ANR grant «Ecologie pour la Gestion des Ecosystèmes et de leurs Ressources» (ECOGER), by the Russian Foundation for Basic Research grant $\mathrm{n}^{\circ}$ 07-04-92170 and the Russian Federation President's grant ${ }^{\circ} \mathrm{MK}-653.2007 .4$.

\section{References}

van Achterberg, C. 1993. Revision of the subfamily Macrocentrinae Foerster (Hymenoptera: Braconidae) from the Palaearctic region. Zool. Verh. Leiden 286: 110.

van Achterberg, C. \& Haeselbarth, E. 1983. Revisionary notes on the European species of Macrocentrus Curtis sensu stricto (Hymenoptera: Braconidae). Entomofauna 4: 37-59.

Agustì, N., Bourguet, D., Spartato, T., Delos, M., Eychenne, N. \& Arditi, R. 2005. Detection, identification and geographical distribution of larval parasitoids using molecular markers. Mol. Ecol. 14: 3267-3274.

Baker, W.A., Bradley, W.G. \& Clark, C.A. 1949. Biological control of the European corn borer in the United States. USDA Tech. Bull. 983: 1-185. 
Baker, M.D., Vossbrinck, C.R., Didier, E.S., Maddox, J.V. \& Shadduck, J.A. 1995. Small subunit ribosomal DNA phylogeny of various microsporidia with emphasis on AIDS related forms. J. Euk. Microbiol. 42: 564-570.

Barney, J.N., Hay, A.G. \& Weston, L.A. 2005. Isolation and characterization of allelopathic volatiles from mugwort (Artemisia vulgaris). J. Chem. Ecol. 31: 247-265.

Bates, D. \& Maechler, M. 2009. Lme4: linear mixed-effects models using S4 classes. R package version 0.999375-31. URL http://CRAN.R-project.org/package=lme4.

Berdegue, M., Trumble, J.T., Hare, J.D. \& Redak, R.A. 1996. Is it enemy-free space? The evidence for terrestrial insects and freshwater arthropods Ecol. Entomol. 21: 203-217.

Bethenod, M.-T., Thomas, Y., Rousset, F., Frérot, B., Pélozuelo, L., Genestier, G. \& Bourguet, D. 2005. Genetic isolation between two sympatric host plant races of the European Corn Borer, Ostrinia nubilalis Hübner. II: assortative mating and host plant preferences for oviposition. Heredity 94: 264-267.

Bourguet, D., Bethenod, M.-T., Trouvé, C. \& Viard, F. 2000. Host-plant diversity of the European corn borer Ostrinia nubilalis: what value for sustainable transgenic insecticidal $B t$ maize? Proc. R. Soc. Lond. B 267: 1177-1184.

Cagáň, L., Turlings, T., Bokor, P. \& Dorn, S. 1999. Lydella thompsoni Herting (Dipt., Tachinidae), a parasitoid of the European corn borer, Ostrinia nubilalis Hbn. (Lep., Pyralidae) in Slovakia, Czech Republic and south-western Poland. J. Appl. Entomol. 123: 577-583.

Calcagno, V., Thomas, Y. \& Bourguet, D. 2007. Sympatric host races of the European corn borer Ostrinia nubilalis (Hübner): adaptation to host plants and hybrid performance. J. Evol. Biol. 20: $1720-1729$.

Campos, F., Donskov, N., Arnason, J.T., Philogène, B.J.R., Atkinson, J., Morand, P. \& Werstiuk, N.H. 1990. Toxicokinetics of 2,4-dihydroxy-7-methoxy-1,4-benzoxazin-3-one (DIMBOA) in the European corn borer, Ostrinia nubilalis (Hübner). J. Chem. Ecol. 15: 1989-2001.

Chen, Y.H. \& Welter, S.C. 2007. Crop domestication creates a refuge from parasitism for a native moth. J. Appl. Ecol. 44: 138245 .

Day, W.H. 1994. Estimating mortality caused by parasites and diseases of insects: comparisons of the dissection and rearing methods. Environ. Entomol. 23: 543-550.

De Nardo, E.A.B. \& Hopper, K.R. 2004. Using the literature to evaluate parasitoid host ranges: a case study of Macrocentrus grandii (Hymenoptera: Braconidae) introduced into North America to control Ostrinia nubilalis (Lepidoptera: Crambidae). Biol. Control. 31: 280-295.

Denno, R.F., Larsson, S. \& Olmstead, K.L. 1990. Role of enemyfree space and plant quality in host-plant selection by willow beetles. Ecology 71: 134-137.

Ding, D., Swedenborg, P.D. \& Jones, R.L. 1989a. Chemical stimuli in host-seeking behavior of Macrocentrus grandii Goidanich (Hymenoptera: Braconidae). Ann. Ent. Soc. Amer. 82: 232-236

Ding, D., Swedenborg, P.D. \& Jones, R.L. 1989b. Plant odor preferences and learning in Macrocentrus grandii (Hymenoptera: Braconidae), a larval parasitoid of the European corn borer, Ostrinia nubilalis (Lepidoptera: Pyralidae). J. Kansas Entomol. Soc. 62: 164-176.

Drès, M. \& Mallet, J. 2002. Host races in plant-feeding insects and their importance in sympatric speciation. Philos. Trans. $R$. Sco. B 357: 471-492.
Edwards, O.R. \& Hopper, K.R. 1998. Using superparasitism by a stem borer parasitoid to infer a host range. Ecol. Entomol. 24: 7-12.

Feder, J.L. 1995. The effect of parasitoids on sympatric host races of Rhagoletis pomonella (Diptera: Tephritidae). Ecology 76: 801813.

Feder, J.L., Berlocher, S.H., Roethele, J.B., Dambroski, H., Smith, J.J., Perry, W.L., Gavrilovic, V., Filchak, K.E. \& Aluja, M. 2003. Allopatric genetic origins for sympatric host-plant shifts and race formation in Rhagoletis. Proc. Natl Acad. Sci. USA 100: 10314-10319.

Folmer, R.H.A., Folkers, P.J.M., Kaan, A., Jonker, A.J., Aelen, J.M.A., Konings, R.N.H. \& Hilbers, C.W. 1994. Secondary structure of the single-stranded DNA binding protein encoded by filamentous phage Pf3 as determined by NMR. Eur. J. Biochem. 224: 663-676.

Frolov, A.N., Bourguet, D. \& Ponsard, S. 2007. Reconsidering the taxonomy of several Ostrinia species in the light of reproductive isolation: a tale for E. Mayr. Biol. J. Linn. Soc. 91: 49-72.

Galichet, P.F., Riany, M. \& Agounke, D. 1985. Bioecology of Lydella thompsoni Herting, (Dip. Tachinidae) within the Rhône delta in Southern France. Entomophaga 30: 315-328.

Gay, J.P. 1999. Maïs, mythe ou réalité. Atlantica, Biarritz.

Gratton, C. \& Welter, S. 1999. Does "enemy-free space" exist? Experimental host shifts of an herbivorous fly. Ecology 80: 773-785.

Grenier, S., Anglade, P., Naibo, B., Galichet, P.F. \& Hawlitzky, N. 1990. Enquête sur la répartition des tachinaires (Diptera: Tachinidae) parasïtoides de la pyrale du maïs Ostrinia nubilalis (Lepidoptera: Pyralidae) en France (1985-1987). Entomophaga 35: 485-492.

Heard, S.B., Stireman, J.O. III, Nason, J.D., Cox, G.H., Kolacz, C.R. \& Brown, J. 2006. On the elusiveness of enemy-free space: spatial, temporal, and host-plant-related variation in parasitoid attack rates on three gallmakers of goldenrods. Oecologia 150: 421-434.

Howard, J. \& Berlocher, H.S. 1998. Endless Forms - Species and Speciation. Oxford University Press, Oxford.

Hsiao, T.H., Holdaway, F.G. \& Chiang, H.C. 1966. Ecological and physiological adaptations in insect parasitism. Entomol. Exp. Appl. 9: 113-123.

Hu, J., Zhu, X.-X. \& Fu, W.-J. 2003. Passive evasion of encapsulation in Macrocentrus cingulum Brischke (Hymenoptera: Braconidae), a polyembryonic parasitoid of Ostrinia furnacalis Guenée (Lepidoptera: Pyralidae). J. Insect. Physiol. 49: 367-375.

Ironside, J.E., Dunn, A.M., Rollinson, D. \& Smith, J.E. 2003. Association with host mitochondrial haplotypes suggests that feminizing microsporidia lack horizontal transmission. J. Evol. Biol. 16: 1077-1083.

Jeffries, M.J. \& Lawton, J.H. 1984. Enemy-free space and the structure of ecological communities. Biol. J. Linn. Soc. 23: 269286.

Jones, R.L. 1996. Semiochemicals in host and mate finding behavior of Macrocentrus grandii Goidanich (Hymenoptera: Braconidae). Fla. Entomol. 79: 104-108.

Kramer, J.P. 1959. Studies on the morphology and life history of Perezia pyraustae Paillot (Microsporidia: Nosematidae). Trans. Am. Microsc. Soc. 78: 336-342.

Kuske, S., Babendreier, D., Adwards, P.J., Turlings, T.C.J. $\delta$ Bigler, F. 2004. Parasitism of non-target lepidoptera by mass 
released Trichogramma brassicae and its implication for the larval parasitoid Lydella thompsoni. Biocontrol 49: 1-19.

Leniaud, L., Audiot, P., Bourguet, D., Genestier, G., Frérot, B., Lee, S.F., Malausa, T., Le Pallec, A.-H., Souqual, M.-C. \& Ponsard, S. 2006. Genetic structure of European and Mediterranean maize borers on several wild and cultivated host plants. Entomol. Exp. Appl. 120: 51-62.

Lewis, L.C., Sumerford, D.V., Bing, L.A. \& Gunnarson, R.D. 2006. Dynamics of Nosema pyrausta in natural populations of the European corn borer, Ostrinia nubilalis: a six-year study. Biocontrol 51: 627-642.

Lupolli, R., Marion-Poll, F., Pham-Delegue, M.-H. \& Masson, C. 1990. Effet d'émissions volatiles de feuilles de maïs sur les préférences de pontes chez Ostrinia nubilalis (Lepidoptera: Pyralidae). CRAS 311: 225-230.

Malausa, T., Bethenod, M.-T., Bontemps, A., Bourguet, D., Cornuet, J.-M. \& Ponsard, S. 2005. Assortative mating in sympatric host races of the European corn borer. Science 308: 258-260.

Malausa, T., Leniaud, L., Martin, J.-F., Audiot, P., Bourguet, D., Ponsard, S., Lee, S.-F., Harrison, R.G. \& Dopman, E. 2007a. Molecular differentiation at nuclear loci in French host races of the European corn borer (Ostrinia nubilalis). Genetics 176: 2343-2355.

Malausa, T., Dalecky, A., Ponsard, S., Audiot, P., Streiff, R., Chaval, Y. \& Bourguet, D. 2007b. Genetic structure and gene flow in French populations of two Ostrinia taxa: host races or sibling species? Mol. Ecol. 16: 4210-4222.

Malausa, T., Pélissié, B., Piveteau, V., Pélissier, C., Bourguet, D. \& Ponsard, S. 2008. Differences in oviposition behaviour of two sympatric sibling species of the Ostrinia genus. Bull Entomol. Res. 98: 193-201.

Martel, C., Réjasse, A., Rousset, F., Bethenod, M.-T. \& Bourguet, D. 2003. Host-plant associated genetic differentiation in Northern French populations of the European corn borer. Heredity 90: 141-149.

Martinez, M. \& Reymonet, C. 1991. Les hôtes de Pseudoperichaeta nigrolineata et de P. palesoidea (Dipt.: Tachinidae). Entomophaga 36: $227-233$.

Monetti, L.R., Malvar, A., Ordàs, A. \& Cordero-Rivera, A. 2003. Parasitoid incidence and diversity on maize stem borers Sesamia nonagrioides Lefèbvre and Ostrinia nubila Hübner in NW Spain. Maydica 48: 133-139.

Ode, P.J. 2006. Plant chemistry and natural enemy fitness: effects on herbivore and natural enemy interactions. Annu. Rev. Entomol. 51: 163-185.

Ohsaki, N. \& Sato, Y. 1990. Avoidance mechanisms of three Pieris butterfly species against the parasitoid wasp Apanteles glomeratus. Ecol. Entomol. 15: 169-176.

Ohsaki, N. \& Sato, Y. 1994. Food plant choice of Pieris butterflies as a trade-off between parasitoid avoidance and quality of plants. Ecology 75: 59-68.

Oppenheim, S.J. \& Gould, F. 2002. Behavioral adaptations increase the value of enemy-free space for Heliothis subflexa, a specialist herbivore. Evolution 56: 679-689.

Parker, H.L. 1931. Macrocentrus gifuensis Ashmead, polyembryonic Braconid parasite in the European Corn Borer. USDA Tech. Bull. 230: 1-63.
Price, P.W., Bouton, C.E., Gross, P., McPheron, B.A., Thompson, J.N. \& Weiss, A.E. 1980. Interactions among three trophic levels: influence of plants on interaction between insect herbivores and natural enemies. Ann. Rev. Ecol. Syst. 11: 41-65.

R Development Core Team 2007. R: A Language and Environment for Statistical Computing. R. Foundation for Statistical Computing, Vienna. URL http://www.R-project.org.

Rundle, H.D. \& Nosil, P. 2005. Ecological speciation. Ecol. Lett. 8: 336-352.

Schluter, D. 2001. Ecology and the origin of species. TREE 16: 372-380.

Schnee, C., Köllner, T.G., Held, M., Turlings, T.C.J., Gershenzon, J. \& Degenhardt, J. 2006. The products of a single maize sesquiterpene synthase form a volatile defense signal that attracts natural enemies of maize herbivores. Proc. Natal Acad. Sci. 103: 1129-1134.

Singer, M.S., Carrière, Y., Theuring, C. \& Hartmann, T. 2004. Disentangling food quality from resistance against parasitoids: diet choice by a generalist caterpillar. Am. Nat. 164: 423-429.

Sisterson, M.S. \& Gould, F.L. 1999. The inflated calyx of Physalis angulata: a refuge from parasitism for Heliothis subflexa. Ecology 80: $1071-1075$.

Smith, M.M. 1996. Biological control with Trichogramma: advances, successes, and potential of their use. Annu. Rev. Etomol. 41: 375-406.

Stireman, J.O. III, Nason, J.D. \& Heard, S.B. 2005. Hostassociated genetic differentiation in phytophagous insects: general phenomenon or isolated exceptions? Evidence from a goldenrod-insect community. Evolution 59: 2573-2587.

Thomas, Y., Bethenod, M.-T., Pélozuelo, L., Frérot, B. \& Bourguet, D. 2003. Genetic isolation between two sympatric host-plant races of the European corn borer, Ostrinia nubilalis Hübner. I. Sex pheromone, moth emergence timing, and parasitism. Evolution 57: 261-273.

Thompson, W.R. \& Parker, H.L. 1928. The European corn borer and its controlling factors in Europe. USDA Tech. Bull. 59: $1-62$.

Tilmon, K.J., Danforth, B.N., Day, W.H. \& Hoffman, M.P. 2000. Determining parasitoid species composition in a host population: a molecular approach. Ann. Entomol. Soc. Am. 93: 640647.

Turlings, T.C.J. \& Benrey, B. 1998. Effects of plant metabolites on the behavior and development of wasps. Ecoscience 5: $321-$ 333.

Udayagiri, S. \& Jones, R.L. 1993. Variation in flight response of the specialist parasitoid Macrocentrus grandii goidanich to odours from food plants of its European corn borer host. Entomol. Exp. Appl. 69: 183-193.

Weiss, L.M., Zhu, X., Cali, A., Tanowitz, H.B. \& Wittner, M. 1994. Utility of microsporidian rRNA in diagnosis and phylogeny: a review. Folia Parasitol. 41: 81-90.

White, J.A. \& Andow, D.A. 2005. Host-parasitoid interactions in a transgenic landscape: spatial proximity effects of host density. Environ. Entomol. 34: 1493-1500.

Received 12 February 2009; revised 19 October 2009; accepted 27 October 2009 